\title{
Kewajiban dalam Pemikiran Immanuel Kant dan Relevansinya dengan Akhlak Islam
}

\author{
Oleh: \\ Rahmat Effendi* \\ Magister AFI Universitas Islam Negeri Sunan Kalijaga Yogyakarta \\ rahmateffendiyessa97@gmail.com
}

\begin{abstract}
Many thinkers discuss ethics as something inherent in life, one of which is Immanuel Kant. Kant, who is known as a transcendent-rationalist philosophy and founder of criticism, stated the importance of ethical obligations based on the reason for humans. Through his criticism of pure reason (pure reason) and practical reason (practical reason) led to a concept of the highest ethics of happiness, where happiness now can not be achieved without ethics purely based on duty. This is also in line with the teachings of Islam that with a commendable character lead humans to the highest happiness, namely the encounter with God. Islam teaches morals that are based on reason in addition to the main foundation of the Koran and hadith. Then the obligation to do good basically can be recognized by reason without any encouragement from various directions. This article will discuss and show the relevance of ethical obligations and Islamic ethics which are consistent and need not be contested. This research is based on library research using descriptiveanalytical and holistic methods. In the end, Western ethical thinking is compatible with Islamic ethics.
\end{abstract}

Keywords: Immanuel Kant, ethics, duty, happiness, Islam

\section{A. PENDAhULUAN}

Filsafat sebagai cara pandang dan pola pikir manusia telah masuk dalam berbagai aspek kehidupan. Karena filsafat yang dikenal sebagai jalan hidup (way of life) memberikan sumbangsih dalam berbagai aliran pikiran, paham, ideologi, disiplin ilmu, hingga pada nilai-nilai keagamaan. Bahkan filsafat disebut dengan induk dari ilmu pengetahuan (mater scientarium, mother of science) yang melahirkan berbagai macam cabang ilmu. Hal ini kemudian ditandai pula dengan adanya pembagian wilayah kajian filsafat secara umum maupun khusus. Dari segi umum cakupannya meliputi epistemologi, kosmologi, mantik, bahkan sains. Adapun dari segi khusus meliputi metafisika, jiwa, etika, sejarah, dan politik.

Menarik untuk dikaji dalam aliran filsafat khusus yaitu etika. 
Etika sebagai wujud tindak tanduk perilaku seseorang berbeda dengan filsafat yang lebih memerhatikan pemikiran ketimbang tindakan. Etika menyelidiki norma moral yang melekat pada seseorang maupun kelompok komunitasnya. Meskipun begitu, etika yang berlandaskan pemikiran filosofis menunjukkan bagaimana nilai etika tersebut lahir dari pemikiran yang mendalam. Di sisi lain, adanya berbagai pengaruh rasionalitas, intuisi, maupun melihat praktek yang terjadi dalam kehidupan turut memberikan pengaruh terhadap suatu pandangan etika. Etika yang dipraktekkan oleh manusia juga memiliki sistem moral dan standar ukuran dalam tindakan. Moral menjadi penentu baik atau buruknya seseorang. Nilai ukuran kepraktisan turut menjadi dasar dalam bangunan suatu etika. Hubungan manusia dengan manusia lainnya merupakan suatu simbiosis yang tidak dapat dipisahkan. Karena manusia pada dasarnya adalah makhluk yang perlu akan manusia yang lain (zoon politicon).

Tindakan etis yang dilakukan oleh manusia haruslah menunjukkan cerminan pribadinya. Karena etika adalah suatu yang inhern dalam diri manusia. Etika menunjukkan kepribadian seseorang sebagai sesuatu yang melekat baik secara spontanitas maupun verbal. Adalah aneh jika suatu perbuatan dilakukan tanpa dorongan dari berbagai arah dan pihak manapun. Sungguhpun demikian ada pula konsep etika yang mendasarkan pada kewajiban. Salah satu konsep etika tersebut adalah Etika Kant (Kantian Etics). Etika Kant mendasarkan pada kewajiban tanpa syarat yang berorientasi pada immortalitas diri berupa kebahagiaan. Immortalitas berupa kebahagiaan hakiki akan dapat digapai manusia melalui etika yang baik tanpa mengharap imbalan (prestise). Immortalitas menjadi pencapaian tertinggi yang dirasakan oleh manusia sebagai hasil dari etikanya. Kebahagiaan tidak menutup diri untuk diraih oleh siapapun.

Selaras dengan hal di atas, Islam juga mengajarkan disiplin moral yang disebut dengan akhlak Islam. Akhlak Islam berdasar pada alQuran dan hadits menjadi dasar teologis kewajiban dalam berbuat baik. Kemudian adanya harmonisasi antara iman yang melekat dalam hati menjadikan dasar teologis tersebut dapat terhayati dalam kehidupan. Meskipun begitu tidak menampik peran akal dalam praktiknya. Adanya harmoni antara akal dan hati menjadikan akhlak Islam sebagai jalan moral terbaik yang harus dipraktikkan dalam kehidupan. Karena pada akhirnya akan mengantarkan manusia pada kesempurnaan, kebahagiaan, dan kemuliaan hakiki sebenarnya.

Artikel ini akan mengungkapkan hal di atas. Penelitian dalam artikel ini berbasis studi pustaka (library research) dengan menggunakan metode deskriptif-analitis dan holistika. Dengan begitu dapat mengungkapkan makna kewajiban moral dalam sebuah sistem etika yang memiliki relevansi dengan etika Islam. Sehingga pada akhirnya jelas bahwa dalam kenyataan etika sebagai disiplin moral perlu dalam kehidupan. 


\section{B. BIOGRAFI}

Immanuel Kant lahir pada 22 April 1724 di Konigsberg sebuah kota kecil di Prussia Timur, Jerman. Dia berasal dari kalangan Pietis salah satu sekte Protestan dan Metodis awal. Orientasi etis Pietisme yang sangat kental dan tiadanya penekanan dogma teologis menjadi sebuah ciri khas Kant dan faktor determinan dalam filsafatnya.

Sejak tahun 1740, Kant tertarik belajar filsafat, matematika, dan teologi di Konigsberg. Pada tahun 1755 Kant memulai karirnya sebagia dosen di Konigsberg yang mengajarkan metafisika, logika, etika, dan sains alam. Kemudian meninggalkan perkerjaan tersebut selama 15 tahun. Pada tahun 1770 dia kembali mengajar dan diangkat menjadi guru besar logika dan metafisika. Kant adalah seorang filosof yang dari waktu kecil hingga dewasa dan wafatnya tidak keluar dari kota tercintanya Konigsberg. Kant meninggal pada 12 Februari 1804 di Konigsberg.

Kant adalah seorang penulis yang produktif. Adapun karya-karya yang telah ditulis oleh Kant di antaranya adalah Prolegomena to Any Future Metaphysics (1783); Idea for a Universal History (1784); Fundamental Principles of The Metaphysics Morals (1785); Critique of Pure Reason (1785); Critique of Practical Reason (1788); Critique of Judgment (1790); Religion Within The Limits of Reason Alone (1793); Perpetual Peace (1795); Metaphysics Ethics (1797); Anthropology from a Pragmatic of View (1798).

\section{PEMBAHASAN}

\section{Kritik Kant dan Etika Kant (Deontologi)}

Sebelum lebih jauh membahas deontologi Immanuel Kant, perlu dibahas landasan atau titik tolak Kant dalam membangun sistem etikanya tersebut. Hal ini penting, karena dapat diketahui atas dasar apa Kant membangun sistem etika (ethic system) dan relevansinya terhadap etika tersebut. Bangunan etika Kant didasarkan atas akal murni (pure reason). Inilah yang menjadi fokus kajian dalam buku Kant yang pertama yang berjudul Critique of Pure Reason (Kritik atas Akal Murni). Dalam buku ini Kant membahas sekaligus mengkritik bagaimana sistem rasio manusia bekerja dalam mendapatkan pengetahuan. Dia mengkritik aliran rasionalisme dan empirisme. Bagi Kant, keduanya dapat menjangkau pengetahuan. Akan tetapi apa yang dimaksudkan oleh rasio bukanlah sebatas pada ide-ide yang lahir dalam benak manusia, melainkan berasal pula dari stimulus dari luar melalui pancaindera. Meskipun begitu pengetahuan yang berasal dari rasio juga dapat dikatakan sebagai pengetahuan transendental yang disebutnya dengan a priori. Selanjutnya Kant berusaha membuat sintesis atas kedua aliran ini bahwa pengetahuan benar berasal dari pengalaman, tapi haruslah bersifat dinamis yang dapat berubah sesuai dengan ruang dan waktu. Nilai universalitas, objektivitas, sikap kritis harus ada dalam pengetahuan. Dengan begitu ada kombinasi antara pengalaman dan rasio yang berujung 
pada pengetahuan transenden yang hadir dalam diri manusia.

Proyek besar lainnya yang dilakukan oleh Kant adalah menguji sampai sejauh mana batas-batas rasio manusia. Inilah yang menyebabkan Kant disebut dengan Bapak Kritisisme. Kant melakukan kegiatan ini guna menunjukkan bahwa rasio tidak harus dipandang begitu saja tanpa mengujinya terlebih dahulu. Bagi Kant, pengetahuan a prosteriori dari empirisme dapat bersamaan dengan pengetahuan a priori dari rasionalisme. Inilah yang kemudian menjadi sebuah sintesis besar Kant sehingga pemikirannya disebut sebagai pemikiran transendental.

Kritik Kant dalam buku pertamanya menunjukkan adanya perbedaan dalam memahami sesuatu yang bersifat nomena dan fenomena. Nomena merupakan suatu yang tidak dapat dikonsepsikan oleh akal manusia melalui berbagai kategori yang ada. Sedangkan fenomena merupakan sesuatu yang dapat dikonsepsikan melalui berbagai kategori dan nyata dalam alam empiris. Pendekatan inderawi umumnya mewarnai dalam memahami fenomena. Karena fenomena merupakan fakta dalam alam empiris, maka fenomena tidak termasuk dalam alam imajiner. Akal murni tidak dapat memahami nomena dan itulah yang merupakan batasan rasio. Sains yang ada juga tidak dapat memahami nomena. Di sinilah letak Kant yang membela sains bahwa nomena bukan wilayah sains baik sebagai wilayah kajian maupun pengungkapan. Demi menjawab problem nomena tersebut, maka diperlukan akal praktis untuk memahaminya. Hal inilah yang mendasari terbitnya buku Critique of Practical Reason. Dalam karya ini, Kant tidak hanya memberikan kritik atas akal murni, namun juga memberikan postulat atas permasalahan tersebut. Postulat inilah yang kemudian menjadi dasar dalam bangunan etikanya.

$$
\text { Bagi Kant perlunya }
$$

memahami segala sesuatu yang menjadi fenomena. Fenomena adalah suatu yang tampak dan merupakan lawan dari nomena yang tidak tampak. Ketika memahami fenomena tersebut, mulailah rasio digunakan untuk memahami segala fakta empiris yang terjadi. Sehingga terjadi postulat berupa sintesis antara pengetahuan a priori dengan pengetahuan a posteriori. Memahami fenomena berarti berusaha dengan sekuat tenaga memahami segala sesuatu yang tampak dan berusaha memahaminya sebatas jangkauan manusia. Pengalaman transenden turut masuk dalam ranah ini. Dalam arti bahwa pengalaman tersebut sebagai sesuatu yang dirasakan sebagai pengalaman personal dan dapat dikonsepsi oleh akal. Jauh daripada itu jelas bahwa nomena dan tidak dapat dijangkau oleh akal.

Lebih lanjut, Kant membedakan antara akal budi (verstand) dengan rasio (vernunft). Bagi Kant, akal budilah yang selama ini difungsikan oleh manusia dalam menanggapi dan memahami sesuatu yang menjadi pengetahuan. Akal menjadi tempat manusia dalam mengkonsepsi dan memersepsikan sesuatu. Tetapi rasio bagi Kant adalam daya pencipta pengertianpengertian murni atau yang mutlak 
yang tidak dapat diberikan oleh pengalaman. Pengertian rasio bagi Kant tidak terikat dengan pengalaman dan tidak memiliki nilai konstitutif bagi daya pengenalan manusia. Rasio menjadi tempat intelek dalam mengambil keputusan berupa kesimpulan atas akal. Dengan begitu apa yang disebut rasio bagi Kant adalah suatu daya berpikir manusia yang lebih dari akal dan idea.

\section{Etika Kewajiban dan Imperatif Kategoris}

Gagasan Immanuel Kant tentang etika adalah deontologi. Deontologi secara bahasa berasal dari kata deon yang berarti keharusan, kewajiban, sesuatu yang diwajibkan dan logos berarti ilmu. Dengan begitu secara harfiah deontologi adalah teori tentang kewajiban. Pengertian ringkasnya adalah suatu ilmu yang membahas kewajiban manusia untuk berbuat baik dan menghindari perbuatan buruk. Adapun secara terminologi, deontologi adalah aliran filsafat etika yang memandang bahwa kewajiban moral dapat diketahui dengan rasio tanpa memerhatikan konsekuensinya.

Berbagai definisi dilekatkan pada deontologi untuk memahami makna kewajiban dalam tindaktanduk manusia. Deontologi berkaitan dengan sikap moral seseorang yang mana kewajiban berupa tuntutan dan perintah moral dalam hubungan sosial masyarakat. Juga turut pula mengandung tanggung jawab dan komitmen terhadap konsep-konsep kewajiban. Ajaran deontologi pada dasarnya mengedepankan suatu konsep kewajiban universal, sehingga setiap orang harus berlaku baik dan memandang manusia seutuhnya berdasar pada kewajiban itu sendiri.

Peristilahan ini lebih lanjut dinisbahkan kepada Immanuel Kant. Kant menjadi pelopor adanya kewajiban moral pada setiap diri manusia. Kewajiban tersebut berupa kebaikan tanpa adanya motif dan dorongan dari berbagai arah. Dengan begitu penekanan atas kewajiban dalam bertindak adalah suatu yang wajib dan disadari oleh manusia. Jika terdapat tekanan dari pihak luar dan dorongan dari dalam diri manusia, maka perbuatan tersebut tidak dapat dikatakan kewajiban.

Pengetahuan manusia atas kewajiban moral didasarkan pada maxime. Maxime adalah prinsip subjektif yang menjadi dasar atas kehendak. Kehendak tersebut lahir sebagai prinsip universalitas yang mengarahkan manusia untuk bertindak nyata (konkret). Tindakan tersebut dapat bernilai baik atau buruk. Itu tergantung pada maxime yang ada dalam diri seseorang. Kewajiban bertindak ada karena maxime baik bersifat universalitas menuntut berbuat baik. Kebaikan yang dilakukan merupakan suatu out put yang berlaku secara universal pada setiap diri manusia. Tindakan kongkret merupakan suatu yang harus terealisasikan atas dasar maxime yang baik dan tidak sebatas pada abstraksi saja.

Kewajiban yang menjadi asas dalam konsep etika Kant ini adalah kewajiban manusia yang menjadi suatu adikodrati dalam diri manusia. Segala perbuatan yang bernilai baik atau buruk bukan dinilai dari segi 
akibat yang ditimbulkan. Seseorang berlaku baik, memberi makan, tempat berteduh, dan menyingkirkan duri di jalan memang adalah suatu kebaikan. Karena dari tindakan tersebut memberikan dampak bagi orang lain secara jelas. Di sisi lain, mencuri barang orang lain, membuang sampah sembarangan, hingga korupsi besar-besaran merupakan tindakan buruk yang turut memberikan dampak yang buruk bagi orang lain maupun negara. Bagi Kant, segala hal yang timbul sebagai akibat dari suatu tindakan atau perilaku tidak menunjukkan etika yang sebenarnya. Karena masih memandang perlu adanya akibat yang timbul dari perbuatan tersebut. Kewajiban harus menjadi sesuatu yang meniscaya dalam tindakan manusia. Sehingga dasar manusia untuk bertindak adalah kewajiban.

Selanjutnya, kewajiban yang meniscaya tersebut haruslah sesuai dengan rasio praktis manusia. Tidak mungkin suatu perbuatan atau tindakan dilakukan tanpa adanya penilaian berupa rasio praktis. Kewajiban dari rasio praktis tersebut akan melahirkan kewajiban bertindak baik dan kewajiban untuk menolak segala hal yang buruk. Kehendak baik (guter Wille) pasti ada secara mutlak dalam setiap pribadi manusia. Kebaikan yang dilakukan adalah kebaikan yang pasti bersifat baik oleh akal manusia. Begitu pula keburukan yang tinggalkan pasti bersifat buruk bagi manusia. Dengan begitu pengetahuan moral bukan berasal dari sesuatu yang ada (das Sein), melainkan dari seharusnya (das Sollen). Keharusan dalam bertindak akan mengarahkan tindakan tersebut pada kehendak baik tanpa ada motif dan dorongan pribadi dalam diri manusia.

Menurut Kant, kewajiban bertindak haruslah terlepas dari berbagai dorongan, baik dari dalam (intern) maupun luar (extern). Itulah mengapa kewajiban yang dilakukan atas dasar perintah rasio. Dalam hal ini, perintah berbuat baik terdiri atas dua, pertama, imperatif hipotesis yang memandang suatu perbuatan dilakukan sebagai alat untuk mencapai sesuatu. Hal ini mengindikasikan adanya tujuan yang ingin dicapai dalam suatu kewajiban. Jelas tindakan ini bersifat teleologis. Kedua, imperatif kategoris yang memandang perintah kewajiban sebagai sesuatu yang tidak ada syarat, tidak goyah, tidak mengenal tujuan, dan tidak mempertanyakan kembali atas perintah tersebut. Perintah jenis kedua inilah yang menjadi dasar etika Kant. Konsep etika Kant bersandar pada postulat yang kedua ini. Perintah adalah kewajiban itu sendiri.

Apabila ditilik jauh lagi, kedua jenis imperatif ini saling bertolak belakang. Imperatif hipotesis jelas bersifat teleologis yang memungkinkan setiap sikap moral mengandung maksud dan tujuan. Memang tidak dipungkiri bahwa sesuatu yang diusahakan mengandung dan tujuan sebagai motif. Akan tetapi bagi Kant, hal tersebut jelas tidak murni dan tidak mewujud rasionalitas. Sebaliknya dengan imperatif kategoris, rasionalitas terwujud dalam tindakan moral yang murni tanpa memandang konsekuensi. Berarti tindakan moral yang dilakukan harus terbebas atas segala pamrih sebagai dampaknya. 
Imperatif kategoris menjadikan suatu kewajiban sebagai sesuatu yang benar menurut rasio dan wajib dilakukan. Perbuatan yang ditimbulkan atas rasio kewajiban ini berupa perbuatan baik. Ketika perbuatan tersebut dilakukan, maka perbuatan tersebut tidak dilakukan dengan mengharap imbalan, tidak dengan tujuan, dan tidak ada dorongan dari pihak manapun. Perbuatan tersebut lahir karena kewajiban berdasar rasio. Seseorang anak membantu pekerjaan ayahnya dengan dasar kasihan atau mengharap sesuatu atau juga dapat terselesainya suatu pekerjaan bukanlah dipandang sebagai suatu perbuatan yang baik bagi Kant. Melainkan seharusnya seorang anak yang membantu ayahnya adalah berdasar perintah dalam rasionya bahwa wajib membantu orang tua, tanpa mengharap sesuatu atau dengan tujuan tertentu.

Berdasar hal di atas, suatu perbuatan dinilai baik apabila tidak berdasar dorongan dan tujuan. Dorongan ini erat kaitannya dengan pribadi seseorang. Dorongan selalu menjadi penggerak manusia dalam berbuat. Bagi Kant, dorongan baik dari dalam maupun luar menjadikan perbuatan tersebut memiliki tujuan tertentu. Hal inilah pula yang ditolak oleh Kant. Walau berdasarkan pada sesuatu yang terbesit dalam sanubari manusia, maka itu pula dikategorikan sebagai dorongan. Memang benar bahwa dorongan perlu dalam melakukan sesuatu. Kant melihat lebih jauh, dengan adanya dorongan tersebut membawa implikasi pada suatu perbuatan harus menghasilkan sesuatu dan ini menjadi tujuan.
Bertolak belakang dengan rasio bahwa perbuatan harus berdasar pada kewajiban. Kewajiban yang dilakukan oleh seseorang tidak harus menjadikan segala sesuatu harus sesuai rasio. Melainkan rasio harus dikedepankan dalam melakukan sesuatu.

Kant membagi tindakan atas dasar kewajiban kepada dua bentuk, yaitu tindakan yang sesuai dengan kewajiban dan tindakan yang dilakukan demi kewajiban. Menurut Kant, tindakan pada bentuk pertama tidaklah bersifat moral dan tidak menunjukkan moralitas. Tindakan tersebut sebatas pada pelaksanaan kewajiban yang disebut dengan legalitas (legalitaet). Namun, pada bentuk kedua, tindakan tersebut adalah tindakan moral dan menunjukkan moralitas. Kebaikan yang dilakukan demi kewajiban bersifat an sich, sehingga tindakan tersebut bukan karena kewajiban melainkan demi kewajiban itu sendiri.

Kant juga melihat berbagai motif dalam melakukan tindakan dan kaitannya dengan akibatnya, yaitu pertama, blameworthy berarti tindakan buruk adalah tindakan yang bukan berasal dari akal sehat dan kesadaran moral. Maka jauh dari kewajiban moral. Kedua, acceptable berarti tindakan baik dengan motif salah adalah tindakan pada lahirnya baik. Meskipun begitu melanggar kesadaran moral dan bukan termasuk kewajiban moral. Ketiga, praiseworthy berarti tindakan baik tanpa motif adalah tindakan berasaskan kesadaran moral yang memenuhi unsur kewajiban moral. Kebajikan tertinggi akan dicapai 
tanpa adanya tekanan dari berbagai arah.

Pada kedua motif pertama, tidaklah mengandung moralitas secara utuh, apalagi pada motif pertama. Keduanya menunjukkan adanya suatu sikap moral yang keliru baik dari segi tindakan dan motifnya. Perbuatan buruk bukanlah tindakan moral. Begitu pula perbuatan baik dengan motif yang salah juga tidak termasuk tindakan moral. Postulat tindakan yang diajukan oleh Kant berada pada motif ketiga, kesadaran moral yang memenuhi kewajiban moral.

\section{Moral Kant}

Etika Kant berasas pada kewajiban yang imperatif kategoris tersebut membawa kepada tatanan hidup yang sempurna. Karena dengan adanya kewajiban atas dasar rasio, menjadikan diri manusia terbebas dari berbagai unsur tekanan dan dorongan. Berbagai syarat dalam melakukan perbuatan dikesampingkan demi menjalankan kewajiban. Dengan rasio yang murni manusia dapat mengetahui suatu perbuatan itu wajib dilakukan, maka perbuatan baik tersebut wajib dilakukan. Moralitas menjadi otoritas tertinggi dalam diri dengan mengedepankan akal murni. Nilai moral yang baik menjadi justifikasi atas tindakan moral yang sesuai dengan kewajiban.

Selanjutnya, fokus moral Kant bagi manusia adalah dengan budi pekerti yang luhur mengantarkan pada kebebasan (peace). Kebebasan ini erat kaitannya dengan perintah kewajiban imperatif kategoris.
Dengan adanya kebebasan, manusia memiliki hak atas dirinya sendiri untuk berbuat apapun. Kehendak untuk berbuat tersebut sesuai dengan akalnya. Manusia tidak boleh mendapat tekanan dari pihak luar maupun adanya dorongan dari dalam dirinya. Rasio menjadi dasar bagi manusia dalam menentukan kebebasan. Apabila manusia melakukan sesuatu yang karenanya ada unsur dan syarat, maka hal tersebut adalah suatu yang mengikat. Suatu yang mengikat pada dasarnya adalah memberi batasan pada kebebasan dan hal ini sama dengan terkungkungnya manusia dalam bertindak. Kebebasan dalam bertindak akan menjadikan kewajiban berdasar rasio menjadi tindakan terbaik yang diwujudkan oleh manusia.

Kant juga membangun suatu sistem moral yang independen, humanistik, dan universal. Dengan adanya independensi dalam berbuat menjadikan diri terbebas dari pengaruh apapun. Perbuatan yang diwujudkan adalah perbuatan baik sesuai rasio yang bernilai humanistik. Berarti perbuatan itu menjadikan manusia menjadi manusia seutuhnya (memanusiakan manusia). Manusia menjadi isu sentral dalam moralitas yang setiap tindak-tanduknya bernilai moral, baik itu bernilai baik atau buruk. Sehingga apa yang digagas oleh Kant menjadi suatu konsep etika yang dapat berlaku dan dipraktekkan oleh setiap orang. Terakhir sifat universal berarti kewajiban berbuat baik dapat dilakukan kapan saja, di mana saja, kepada siapa saja sehingga tidak mengenal batas. Manusia berbuat baik atas kehendaknya dan 
dapat dilakukan kepada diri sendiri, orang lain, maupun pada alam tempat tinggalnya.

Bangunan etika Kant berdiri di atas postulat, yaitu; pertama, otonomi (autonomy) berarti perbuatan harus dari kehendak dan kebebasan diri (reihet). Kewajiban yang dilakukan dengan kehendak sendiri itulah yang bermoral. Apabila tidak memiliki kebebasan maka bukan moral. Dengan adanya kebebasan maka timbul kesadaran moral. Kedua, immortalitas (immortality) berarti adanya yang akan didapatkan atas moral yang dibangun dan dipraktekkan dalam kehidupan berupa keabadian dan kebahagiaan tertinggi yang tidak ada dalam kehidupan dunia ini. Ketiga, Tuhan (God) berarti dari Tuhan sumber moralitas dan manusia menghadap padanya. Tuhan harus ada dalam rangka menegakkan dan kewajiban moral. Percaya pada Tuhan adalah suatu hal yang mutlak.

Sesuatu yang baik atau buruk dan bermoral atau tidak bermoral tergantung pada motif dalam melakukannya. Motif tunggal tekad yang baik (good will) adalah kewajiban. Kehendak atau motif yang baik itu adalah kehendak rasional murni (pure reason). Ide Kebaikan Tertinggi dalam immortalitas dan Tuhan dalam postulatnya adalah objek dan tujuan final dari rasio praktis. Bagi Kant rasio praktis secara tidak langsung mengaitkan moral agama. Kewajiban dalam moral agama adalah sebuah keputusan moral individu dalam hidupnya. Maka harus ada secara bersamaan kebebasan (autority), immortalitas jiwa, dan Tuhan. Seraya dengan hal tersebut, moral Kant juga memberikan efek sebagai nilai moral. Nilai moral yang berarti bahwa manusia dalam hubungannya dengan manusia lain mengedepan rasio moral (kewajiban) dalam bertindak. Ini dilakukan demi menjauhi makna ambigusitas moral dalam menegakkan nilai moral. Nilai moral inilah yang menjadi perwujudan pemahaman transenden atas nilai moral.

Moral yang ditunjukkan oleh Kant pada dasarnya adalah argumennya dalam membuktikan adanya Tuhan. Karena dalam akal murni tidak dapat mencapai Tuhan sebagai kenyataan karena bergantung pada rasio dan pengalaman empiris, melainkan harus pada akal praktis. Akal praktis berkaitan dengan tindaktanduk manusia yang ditunjukkan melalui perbuatan. Etika yang baik harus berasal dari kewajiban moral atas dasar rasio praktis. Ketika pengetahuan telah bergerak pada rasio praktis, maka moral akan menjadi bagian daripadanya. Itulah mengapa nomena tidak dapat dipahami melalui akal murni. Nomena hanya dapat dipahami melalui akal praktis. Kant berusaha menggeser paradigma bahwa Tuhan tidak dapat dipahami sebagai pengetahuan murni kepada pengetahuan praktis. Melalui keputusan moral manusia dapat bertindak dalam hidupnya. Sehingga Tuhan diposisikan sebagai Moral Tertinggi dan Penegak Moral Hakiki. Moral yang baik adalah moral yang memiliki nilai-nilai ketuhanan. Imanensi Tuhan dalam moralitas manusia mengantarkan manusia sebagai makhluk yang bertuhan 
dengan puncaknya yaitu kebaikan tertinggi dan kebahagiaan. (virtue and happines).

Melihat lebih jauh lagi, immortalitas sebagai keabadian bagi Kant mewujud dalam kebahagiaan tertinggi. Alasan Kant memilih hal demikian erat hubungannya dengan pembuktian akal praktis sebagai suatu jalan dalam memahami nomena. Nomena yang merupakan sesuatu di luar manusia bukan berarti tidak berhubungan dengan manusia secara empiris, melainkan secara empiris melalui pengalaman batin. Pengalaman batin yang dialami manusia melibatkan alam transeden yaitu Tuhan. Tuhan tidak dapat dijelaskan dengan pendekatan empiris. Melalui akal praktis sebagai pengalaman pribadi (experience of personality) Tuhan dapat dirasakan dan ada dengan keyakinan untuk berbuat baik. Keabadian yang mewujud dalam kebahagiaan dirasakan dalam bentuk tujuan akhir tertinggi tersebut, atas dasar tersebut Tuhan (God) perlu ada dalam ajaran moral. Karena tanpa Tuhan tidak ada nilai standar dalam ajaran moral.

Kebaikan yang dilakukan oleh seseorang menunjukkan bagaimana kadar iman dalam dirinya. Dalam hal ini Kant masuk ke ranah agama. Akan tetapi bukan dalam ranah teoritis melainkan praktis. Iman yang dimaksud adalah keyakinan atas tindakan moral yang dilakukan secara praktis. Atas dasar iman tersebut manusia yakin bahwa Tuhan akan membimbingnya untuk berlaku baik dan menjauhi perbuatan buruk sesuai dengan batas pengetahuannya. Keimanan inilah yang disebut sebagai suara hati manusia. Suara hati manusia menuntut berbuat baik dan meninggalkan perbuatan buruk. Menurut Kant, suara hati bukanlah sesuatu yang bersifat empiris, melainkan bersifat rasio. Karena suara hati bersifat baik, maka suara hati disebut dengan rasio praktis. Pembuktian adanya Tuhan dapat dilakukan melalui rasio praktis, bukan melalui rasio murni

\section{Relevansi Etika Kant dengan Akhlak Islam}

Konsep Etika Kant yang disebut sebagai deontologi tersebut, mendasarkan pada kewajiban atas dasar rasio yang imperatif kategoris. Baik dan buruknya suatu tindakan di dasarkan atas kewajiban. Moralitas yang dibangun manusia adalah kewajiban itu sendiri. Kewajiban berlaku baik haruslah bersifat humanistik dan universal. Rasio murni tidak akan mengarah pada keburukan. Hanya saja dalam prakteknya, manusia kadang kala melakukan sesuatu dilandasi oleh dorongan dari dalam maupun luar dirinya. Inilah yang bagi Kant merusak citra kewajiban tersebut. Selain itu, kebebasan manusia ditekankan dalam rangka mencapai kewajiban berdasar rasio tanpa syarat tersebut.

Puncak etika Kant ini adalah kebahagiaan transenden yang akan dirasakan oleh manusia. Sehingga adanya faktor intuisi secara transendental akan hadir dalam setiap perbuatan setelah dilakukan. Muara dari kewajiban ini adalah kepada Tuhan. Tuhan menjadi dan sumber dan dasar dalam moralitas manusia. Rasio mengenal kewajiban berdasar pada nilai-nilai tersebut. Sehingga 
pada akhir konsep etika Kant mengantarkan pribadi manusia menjadi pribadi yang bermoral, bebas, dan bahagia secara transedental.

Sistem etika Kant yang menekankan pada kewajiban etik yang imperatif kategoris ini, setidaknya memberikan gambaran dan sumbangsih dalam membangun etika manusia ke depannya. Lebih lagi dikaitkan dengan etika agama. Islam sebagai suatu agama juga memiliki sistem etika yang disebut dengan akhlak Islam. Akhlak Islam memuat perintah untuk selalu berbuat baik. Perbuatan yang dilakukan oleh seseorang menjadi cerminan atas dirinya. Lebih lanjut akhlak Islam menjadi sebuah sistem kehidupan dalam Islam yang bersifat adikodrati, humanis, universal, dan transendental. Melihat pemikiran Kant, setidaknya ada beberapa hal yang dapat diambil dan saling bersesuaian dengan akhlak Islam tersebut.

Pada dasarnya konsep etika Kant ini dapat ditarik benang merah dengan akhlak Islam dalam beberapa hal, yaitu:

\section{Dasar kewajiban}

Etika Kant mendasarkan berbuat baik adalah suatu kewajiban berdasar pada rasio. Akhlak Islam menekankan kewajiban berdasar pula pada akal. Akal pada dasarnya dapat menilai suatu perbuatan itu bernilai baik atau buruk. Tanpa adanya tuntunan wahyu pun akal manusia dapat menggapai hal tersebut. Wahyu yang diturunkan menjadi konfirmasi bagi akal dan legitimasi atas perbuatan baik tersebut. Jika ditilik dari segi teoritis, maka hal ini dapat disamakan. Adapun kewajiban berbuat baik dalam wahyu al-Quran maupun hadits tidak pula serta merta dikatakan sebagai dorongan dan tekanan. Memang betul apabila dilihat dari sudut pandang orang awam wahyu menjadi dasar dan legitimasi, sehingga menjadi pendorong dalam melakukan sesuatu. Akan tetapi pada hakikatnya itu sama. Tidak mungkin suatu kewajiban dalam agama hadir tanpa dapat bersesuaian dengan akal manusia. Oleh karenanya kewajiban berbuat baik akan selalu melekat pada diri manusia.

Kewajiban dalam berbuat baik dalam Islam adalah tuntutan agama. Selain selaras dengan akal juga turut menjaga agama itu sendiri. Pada mulanya, kewajiban tersebut sebagai pendorong manusia untuk berbuat kebajikan berlandas agama. Dalam perkembangannya, manusia lambat laun akan memahami bahwa kewajiban yang dituntut oleh agama selaras dengan akal karena berguna dalam kehidupan. Tidak mungkin suatu perintah dan larangan dalam agama ada tanpa ada maksud dan tujuan serta balasan (reward). Meskipun begitu, hal tersebut bukan menjadi alasan dalam bertindak. Adanya nilai ketuhanan dalam setiap diri manusia menjadikan praktik moral dilakukan.

\section{Kebebasan}

Term kebebasan berbuat ditekankan oleh Kant dalam bangunan etikanya. Kebebasan tanpa syarat menyebabkan kewajiban dan keharusan dalam berbuat dapat 
terwujud. Akhlak Islam menjamin akan adanya kebebasan tersebut. Karena sesuatu yang baik dan benar tidak mungkin dapat terbatas. Sebab puncak dari kebaikan dan kebenaran adalah Tuhan. Islam mengajarkan untuk berbuat baik terhadap siapapun. Kebaikan tersebut dimulai dari diri sendiri, orang tua, kerabat, keluarga, tetangga, antarmanusia, dan makhluk lain yang diciptakan oleh Allah SWT. Bahkan berbuat baik juga terhadap Tuhan. Adanya alQuran dan hadits menjadi landasan, pengatur, dan pengarah kebebasan manusia dalam berbuat dan itu semua bermuara pada kebaikan. Kebebasan yang dilegitimasi oleh wahyu Islam mengisyaratkan bahwa manusia berhak menentukan nasib dirinya sendiri dengan catatan masih dalam koridor al-Quran dan hadits.

Persoalan kebebasan dalam bertindak memang menjadi pembahasan hangat dalam kalam klasik. Tidak mesti persoalan tersebut dibawa pada masa kekinian. Karena setiap manusia berhak dan dapat menentukan masa depannya. Apalagi dalam hal kebebasan moral. Kebebasan dalam Islam jika dipandang secara universal memiliki batas. Batas tersebut sesuai dengan sifat manusiawi. Karena kebebasan seseorang akan terbatas dengan kebebasan orang lain. Sehingga dalam prakteknya, tidak mungkin manusia dapat hidup sebebasbebasnya. Di sisi lain, ada pula hukum dan norma agama yang membatasinya. Manusia dapat bertindak moral dengan memerhatikan orang lain dan lingkungannya. Itulah yang disebut dalam ajaran Islam bahwa Islam adalah agama bagi seluruh alam (rahmatan li al-'alamin).

\section{Tujuan akhir}

Setiap tindak tanduk manusia diharapkan dapat memberikan efek sebagai akibat dari perbuatan yang dilakukan. Begitu pula tujuan akhirnya. Etika Kant menyebutkan bahwa tujuan akhir dari etika kewajiban adalah immortalitas dan kebahagiaan tertinggi. Dapat pula disebut dengan kebahagiaan transenden berupa kebahagiaan yang didapat dengan adanya kewajiban berlaku baik. Adanya tujuan ini bukan menjadi motivasi atau pendorong dalam melakukan kewajiban. Melainkan kebahagiaan ini hadir sebagai sesuatu yang dirasakan oleh jiwa manusia di dunia ini (prestise). Pada akhirnya akan sampai pada kebahagiaan dan kebaikan tertinggi yaitu Tuhan. Senada dengan akhlak Islam, bahwa akhlak Islam menuntun manusia kepada pengenalan kepada Allah SWT berupa meneladani sifat Allah SWT dan Nabi Muhammad SAW. Maka pada saat itu, manusia telah meniru sifat Allah SWT dan Nabi SAW sejauh batas kemampuan dan kapasitasnya sebagai manusia. Manusia yang menghiasi dirinya dengan akhlak Tuhan akan mengantarkan dirinya kepada Kebenaran dan Kebahagiaan Tertinggi yaitu Allah SWT.

Transformasi akhlak Islam dalam diri manusia dimulai sejak usia bayi bahkan sedari dalam kandungan ibunya. Kemudian setelah lahir, tumbuh besar melewati fase anakanak, remaja, dewasa, hingga tua. Dalam proses transformasi ini, akhlak 
juga mengalami perkembangan. Sehingga pada puncaknya, manusia akan sampai pada titik kesempurnaan akhlak. Selagi manusia tersebut berusaha memperbaiki akhlak, mengedepankan akhlak terpuji (alakhlaq al-mahmudah), maka akan sampai pada derajat akhlak sempurna (al-akhlaq al-karimah). Disamping itu turut menjauhi berbagai sifat dan akhlak tercela (al-akhlaq mazmumah). Hal demikian dapat dilakukan melalui kewajiban moral yang berorientasi pada nilai-nilai agamis dan Islami.

\section{KESIMPULAN}

Sebagaimana pemaparan di atas, dapat disimpulkan bahwa konsep etika yang digagas oleh Immanuel Kant menekankan kewajiban berlaku baik tanpa syarat. Kewajiban tersebut timbul dari rasio manusia yang mengenal bahwa perbuatan baik wajib dilakukan dan menghidari perbuatan buruk. Kebaikan yang dilakukan harus dilkakukan tanpa syarat dan motif. Jika masih mengandung syarat dan motif, maka perbuatan tersebut tidaklah disebut dengan kebaikan.

\section{Daftar Kepustakaan}

Asdi, Endang Daruni. "Imperatif Kategoris Dalam Filsafat Moral Immanuel Kant." Jurnal Filsafat 23, no. 1 (15 November 1995): 9-19. https://doi.org/10.22146/jf.31 607.

Bagir, Haidar. Islam Risalah Cinta Dan Kebahagiaan. Jakarta: Noura Books, 2019.
Etika Kant juga mengajarkan suatu sistem etika yang humanis dan universal. Tujuan dari etika Kant mengantarkan manusia pada kebahagiaan dan kebaikan transenden yaitu Tuhan. Segala kebajikan akan bermuara padanya sehingga tercapailah tujuan tertinggi kehidupan manusia.

Islam mengajarkan untuk berbuat baik. Perbuatan baik tersebut menjadi kewajiban bagi setiap umat Islam tanpa kecuali. Pada awalnya manusia dituntut untuk berbuat baik karena dorongan perintah al-Quran dan hadits maupun karena belas kasih. Namun lambat laun, Islam menginginkan perbuatan baik sebagai kewajiban tersebut berasal dari diri manusia itu sendiri. Sehingga pada dasarnya etika Kant dan akhlak Islam memiliki benang merah yang dapat diambil sebagai pelajaran yang berharga. Akhlak Islam mengatur hubungan manusia dengan dirinya sendiri, antarmanusia, dengan alam, bahkan dengan Tuhan. Segala bentuk praktek etika Islam menjadi suatu sistem etika yang turut bersifat humanis, universal, dan transendental.

Bagus, Lorens. Kamus Filsafat. Jakarta: Gramedia Pustaka Utama, 2005.

Bertens, K. Etika. Jakarta: Gramedia Pustaka Utama, 1993.

Dahlan, Mohammad. "Pemikiran Filsafat Moral Immanuel Kant (Deontologi, Imperatif Kategoris dan Postulat Rasio Praktis)." Jurnal Ilmiah Ilmu Ushuluddin 8, no. 1 (4 Januari 
2009): $\quad 37-48$. https://doi.org/10.18592/jiu.v8 i1.1369.

Dunya, Sulaiman. al-Tafkir al-Falsafi al-Islami. Kairo: Maktabat alKhanaji, 1967.

Garvey, James. 20 Karya Filsafat Terbesar. Yogyakarta: Kanisius, 2010.

Gusmian, Islah. "Filsafat Moral Immanuel Kant: Suatu Tinjauan Paradigmatik." AlA'raf: Jurnal Pemikiran Islam dan Filsafat 11, no. 2 (30 Desember 2014): 57. https://doi.org/10.22515/ajpif. v11i2.1190.

Hadiwijono, Harun. Sari Sejarah Filsafat Barat 2. Yogyakarta: Kanisius, 1980.

Hamersma, Harry. Pintu Masuk ke Dunia Filsafat. Yogyakarta: Kanisius, 1981.

Hardiman, F. Budi. Pemikiranpemikiran yang Membentuk Dunia Modern: Dari Machiavelli sampai Nietzsche. Jakarta: Penerbit Erlangga, 2011.

Huda, Samsul. "Diskursus Tuhan dalam Pemikiran Etika Immanuel Kant: Memaknai Agama dalam Kehidupan Manusia." Media Akademika 26, no. 1 (2011): 1-20.

Ibda, Hamidulloh. Filsafat Umum Zaman Now. Pati: CV. Kataba Group, 2018.

Iqbal, Imam. "Makna Beragama Menurut Immanuel Kant
Dalam Religion Within the Limits of Reasonalone." Refleksi: Jurnal Filsafat Dan Pemikiran Islam 15, no. 2 (1 Juli 2015): 227-45. https://doi.org/10.14421/ref.2 $015 . \% x$.

Javaphilosophy. "Mengenal Konsep Etika Immanuel Kant." Graha Filsafat (blog), 13 April 2015. https://grahafilsafat.wordpress .com/2015/04/13/konsepetika-modern-immanuel-kant$2 /$.

Kant, Immanuel. Kritik Atas Akal Budi Praktis judul asli Critique of Practical Reason. Yogyakarta: Pustaka Pelajar, 2018.

Lipscomb, Benjamin J. Bruxvoort, dan James Krueger. Kant's Moral Metaphysics: God, Freedom, and Immortality. New York: Walter de Gruyter, 2010.

Magnis-Suseno, Franz. Pijar-Pijar Filsafat: Dari Gatholoco ke Filsafat Perempuan, Dari Adam Müller ke Postmodernisme. Yogyakarta: Kanisius, 2005.

Maiwan, Mohammad. "Memahami Teori-Teori Etika: Cakrawala Dan Pandangan." Jurnal Ilmiah Mimbar Demokrasi 17, no. 2 (1 April 2018): 190212. https://doi.org/10.21009/jimd. v17i2.9093.

Mustain. "Etika dan Ajaran Moral Filsafat Islam: Pemikiran Para Filosof Muslim tentang 
Kebahagiaan." ULUMUNA 17, no. 1 (25 Juni 2013): 191. https://doi.org/10.20414/ujis.v $17 \mathrm{i} 1.177$.

Muthmainnah, Lailiy. "Tinjauan Kritis terhadap Epistemologi Immanuel Kant (1724-1804)." Jurnal Filsafat 28, no. 1 (28 Februari 2018): 74-91. https://doi.org/10.22146/jf.31 549.

Nasution, Harun. Teologi Islam: Aliran-aliran, Sejarah, Analisa, dan Perbandingan. Jakarta: Universitas Indonesia Press, 1986.

Noor, Irfan. "Teori Pengetahuan Immanuel Kant Dan Implikasinya Terhadap Batas Ilmu." Jurnal Ilmiah Ilmu Ushuluddin 9, no. 1 (4 Januari 2010): 43-58. https://doi.org/10.18592/jiu.v9 i1.1409.

Purnama, Fahmi Farid. "Mengurai Polemik Abadi Absolutisme Dan Relativisme Etika." Living Islam: Journal of Islamic Discourses 1, no. 2 (28 November 2018): 273-98. https://doi.org/10.14421/lijid. v1i2.1731.

Rahman, Masykur Arif. Buku Pintar Sejarah Filsafat Barat. Yogyakarta: IRCiSoD, 2013.

Stratton-Lake, Philip. Kant, Duty, and Moral Worth. London and New York: Routledge, 2005.

Sumarna, Elan. "Filsafat Etika Immanuel Kant." adoc.tips.
Diakses 7 Juni 2020. https://adoc.tips/filsafat-etikaimmanuel-kant-oleh-elansumarna-kata-kunci-so.html.

Taufik, Muhammad. "Etika dalam Perspektif Filsafat Islam." Diakses 8 Juni 2020. https://scholar.google.com/sch olar?client=firefox $-b-$ $\mathrm{d} \& u m=1 \&$ ie $=$ UTF$8 \& \operatorname{lr} \& q=$ related:p6KMW2Xff6kM:scholar.google.com/.

Tjahjadi, Simon Petrus L. "Eksistensi Tuhan Menurut Immanuel Kant: Jalan Moral Menuju Tuhan." Jurnal Orientasi Baru 18, no. 2 (16 Juli 2018): 16376.

Wepman, Joseph M., dan Ralph W. Heine. Concepts of Personality. New Brunswick and London: Transaction Publishers, 2008.

Wood, Allen W. Kant's Moral Religion. Ithaca and London: Cornell University Press, 2009.

Yazdi, Ali Asgari. "Sejarah Skeptisisme: Jatuh Bangun Paham Keraguan atas Kebenaran," 2016. https://books.google.co.id/boo ks?id=DDBODwAAQBAJ\&p $\mathrm{g}=\mathrm{PA} 213 \& \mathrm{dq}=$ nomena $+\mathrm{dan}+\mathrm{f}$ enomena\&hl=en\&sa=X\&ved $=2$ ahUKEwjz9MSZ0qvrAhV KX30KHQyLD84Q6AEwAX oECAUQAg\#v $=$ onepage $\& \mathrm{q}=$ nomena\%20dan $\% 20$ fenomena $\& \mathrm{f}=$ false. 